\title{
VARIATION OF BIOMETRIC PARAMETERS AND C, N, AND P CONCENTRATIONS OF Oryza glumaepatula AT DIFFERENT DEPTHS OF AN AMAZONIAN LAKE IMPACTED BY BAUXITE TAILINGS (LAKE BATATA, PARÁ, BRAZIL)
}

\author{
ENRICH-PRAST, A., ${ }^{1,2}$ ESTEVES, F. A. ${ }^{1}$ and BREVES, A. R. ${ }^{1}$ \\ ${ }^{1}$ Lab. Limnologia, Universidade Federal do Rio de Janeiro, Dep. Ecologia, Inst. Biologia, CCS, \\ Cidade Universitária, C.P. 68020, CEP 21940-590, Rio de Janeiro, RJ, Brazil \\ ${ }^{2}$ Department of Microbial Ecology, University of Aarhus, Ny Munkegade 540, Aarhus, Denmark, \\ e-mail: alex.prast@biology.au.dk \\ Correspondence to: Francisco A. Esteves, Lab. Limnologia, Universidade Federal do Rio de Janeiro, \\ Dep. Ecologia, Inst. Biologia, CCS, Cidade Universitária, C.P. 68020, CEP 21940-590, \\ Rio de Janeiro, RJ, Brazil, e-mail: festeves@ biologia.ufrj.br \\ Received October 18, 2000 - Accepted January 25, 2001 - Distributed February 28, 2002
}

(With 3 figures)

\begin{abstract}
Lake Batata is a typical Amazonian clear water lake which has undergone anthropogenic impacts. Thirty percent of its total area has been covered with bauxite tailings. Thus, it is possible to distinguish two areas in this ecosystem: the impacted and the natural. The goal of this research was to study $\mathrm{C}, \mathrm{N}$, and $\mathrm{P}$ content variation and the values of biomass, length, density, and culm diameter of Oryza glumaepatula at different depths in the natural and impacted areas of Lake Batata. The results obtained in this research suggest that the availability of $\mathrm{P}$ and $\mathrm{N}$, in both water and sediment, is lower at the shallow site when compared to the deeper sites. On the other hand, $\mathrm{C}$ concentrations decreased as $\mathrm{P}$ and $\mathrm{N}$ concentrations increased. This may be explained by the structural function of $\mathrm{C}$ in aquatic macrophytes. At shallower sites, due to the reduced water column, individuals invest in supporting structures that display high $\mathrm{C}$ concentrations. The higher density and biomass of $O$. glumaepatula at the intermediate site indicate that this area presents the best conditions for germination and establishment of individuals of this species. The chemical composition and biometric parameters of $O$. glumaepatula have shown that this population has higher spatial variation in the natural area. In the impacted area, the absence of significant variations in $\mathrm{N}$ and $\mathrm{P}$ concentrations in O. glumaepatula among the three sampled sites promotes higher homogeneity in the stands. The high C:P and N:P ratios indicate that, in the impacted area, $\mathrm{P}$ is more limiting to the development of $O$. glumaepatula than it is in the natural area. The reduced values of biomass and density of O. glumaepatula in the impacted area suggest that the bauxite tailings limit the development of this population.
\end{abstract}

Key words: Oryza glumaepatula, chemical composition, biometrics, Amazonian Region, bauxite tailings.

\section{RESUMO}

\section{Variação de parâmetros biométricos e concentrações de C, N e P em Oryza glumaepatula em diferentes profundidades de um lago amazônico impactado por rejeito de bauxita (Lago Batata, Pará, Brasil)}

O Lago Batata é um típico lago amazônico de águas claras que sofreu impactos antropogênicos. De sua área total, $30 \%$ foi recoberta com rejeito de bauxita. Desta forma, pode-se distinguir duas áreas nesse ecossistema: impactada e natural. O objetivo desta pesquisa foi estudar a variação de $\mathrm{C}, \mathrm{N}$ e $\mathrm{P}$ e os valores de biomassa, comprimento, densidade e diâmetro do colmo de Oryza glumaepatula 
em diferentes profundidades, nas áreas impactada e natural, do Lago Batata. Os resultados obtidos na pesquisa sugerem que as disponibilidades de $\mathrm{P}$ e N, tanto na água como no sedimento, são menores no ponto raso quando comparado com os pontos mais profundos. Por outro lado, as concentrações de $\mathrm{C}$ diminuíram à medida que as concentrações de $\mathrm{P}$ e $\mathrm{N}$ aumentaram. Isto pode ser explicado pela função estrutural do $\mathrm{C}$ em macrófitas aquáticas. Nos pontos mais rasos, devido à reduzida coluna d'água, indivíduos investem em estruturas de suporte com elevadas concentrações de C. A elevada densidade e biomassa de $O$. glumaepatula no ponto intermediário indica que essa área apresenta as melhores condições para germinação e estabelecimento de indivíduos dessa espécie. A composição química e os parâmetros biométricos de $O$. glumaepatula mostraram que essa população possui elevada variação espacial na área natural. $\mathrm{Na}$ área impactada, a menor variação nas concentrações de $\mathrm{N}$ e $\mathrm{P}$ nos três pontos de amostragem promove alta homogeneidade nos estandes. As altas razões C:P e N:P indicam que, na área impactada, o P é mais limitante para o desenvolvimento de O. glumaepatula do que na área natural. Os reduzidos valores de biomassa e densidade de O. glumaepatula na área impactada sugerem que o rejeito de bauxita limita o desenvolvimento dessa população.

Palavras-chave: Oryza glumaepatula, composição química, biométricos, região amazônica, rejeito de bauxita.

\section{INTRODUCTION}

Several species of aquatic macrophytes such as Oryza glumaepatula, Echinochloa polystachya, Paspalum repens, Paspalum pasunculatum, and Luziola spruceana, whose life cycles are influenced by the variation in the water level (Junk \& Piedade, 1993; Piedade, 1995) are found in the Amazon region. Several authors, such as Junk \& Piedade (1993), Piedade (1995), Rubim (1995), and EnrichPrast (1998), have shown that the biometric parameters and concentration of chemical elements in the biomass of these aquatic macrophyte species are determined by the water level variation.

The genus Oryza encompasses 2 domestic species, and some 20 wild species of rice (the domestic having been selected from the wild species), found throughout the tropical and subtropical regions of the world (Morishima \& Martins, 1994).

The species Oryza glumaepatula Steud is found in Amazonian Region lakes and rivers and germinates during the dry phase, in recently exposed lowlands with direct incidence of light. After germination, this species develops as a terrestrial plant; however, as water level rises, it is covered by water, behaving as an aquatic plant (EnrichPrast, 1998). Oryza glumaepatula colonizes transition zones between areas with periodically flooded vegetation (igapó forest) and those which are permanently flooded.

Lake Batata, where this research was carried out, stands out from other Amazonian lakes on account of the great magnitude of anthropic impact. For ten years, tailing effluent was dumped into its water because of bauxite extraction in the area. As a result, two areas are now identified at Lake Batata: one impacted by bauxite tailings, and a natural area. According to Esteves et al. (1990), the impacted area shows differences in regarding the biota structure as well as nutrient cycling. Oryza glumaepatula may cover up to $90 \%$ of the area colonized by aquatic macrophytes at Lake Batata and grows in natural and impacted areas.

The goal of this research was to study the carbon, nitrogen, and phosphorus content and the values of biomass, length, density, and culm diameter of O. glumaepatula at different depths in the natural and impacted areas of Lake Batata.

\section{STUDY AREA}

Lake Batata is located in the basin of the Trombetas River, on its right margin, between coordinates $1^{\circ} 20^{\prime}$ and $1^{\circ} 35^{\prime} \mathrm{S}$ and $56^{\circ} 15^{\prime}$ ' and $56^{\circ} 25^{\prime} \mathrm{W}$, close to the town of Porto Trombetas, municipality of Oriximiná (PA). This lake is a clear water ecosystem according to the classification proposed by Sioli (1984). The morphometric characteristics of Lake Batata were described by $\mathrm{Pa}$ nosso et al. (1995). This lake is set apart from other Amazonian lakes because about $50,000 \mathrm{~m}^{3} \mathrm{~d}^{-1}$ of bauxite tailings were dumped in it for ten years (1979-1989), filling 30\% of its total area. The tailings are deposited over the natural sediment and suspended in the water column. Lake Bata- 
ta, like most lakes in the Amazonian Region, displays a marked variation in water level, which reaches more than $8 \mathrm{~m}$ in some years.

The Lake Batata margins are colonized by the aquatic macrophyte $O$. glumaepatula, locally known as wild rice ("arroz bravo"). This species germinates when the sediment is exposed, beginning its terrestrial phase which may last for about two months. After the water level begins rising, O. glumaepatula individuals grow as fast as the waters rise (Enrich-Prast, 1998), which results in the presence of leaves above water surface at all times, allowing for greater light absorption.

At the impacted area, $O$. glumaepatula grows over the bauxite tailings, but in this area the amount of land available for colonization is smaller than in the natural area. This phenomenon may be attributed to the consolidated blocks of bauxite tailings comprising the sediment of the impacted area. The blocks take shape in low-water seasons, when the bauxite tailings are exposed for some months. Crevices are formed between the blocks of tailings, and can reach close to $10 \mathrm{~cm}$ in width, where the $O$. glumaepatula individuals germinate. The sediment of the impacted area may, therefore, be described as a mosaic comprised of blocks of bauxite tailings surrounded by crevices where $O$. glumaepatula grows.

\section{MATERIALS AND METHODS}

The collection of $O$. glumaepatula samples at different depths was performed at Lake Batata in two areas, one impacted by bauxite tailings and the other in a natural spot (without tailing influence). Three sampling sites were established at the littoral zone of these two areas: deep, intermediate, and shallow sites. (Fig. 1a and b). All were submersed at sampling time. The deep point was located in the furthermost area of the macrophyte stand, close to the limnetic zone. The shallow site was located at the other end of the stand, close to the igapó forest. The intermediate site was located between the other two.
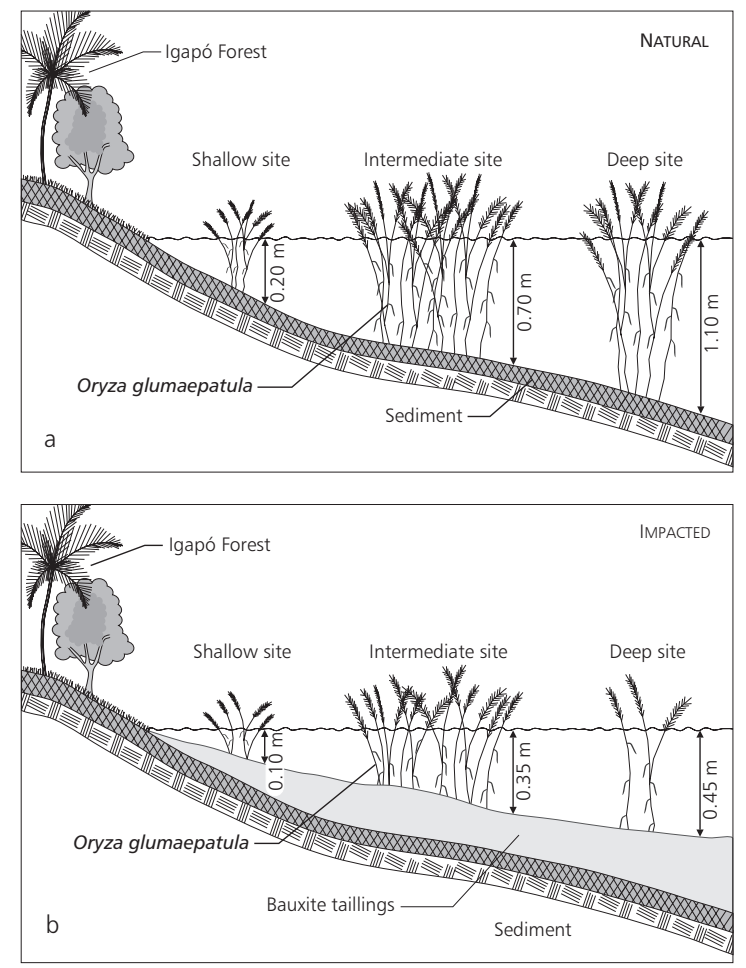

Fig. 1 - Horizontal distribution of Oryza glumaepatula at the sampling sites in natural (a) and impacted (b) areas. 
In the natural area, deep, intermediate, and shallow sites had depths of 1.1, 0.7, and $0.2 \mathrm{~m}$, respectively (Fig. 1a), and the distance between the deep and shallow sites was $50 \mathrm{~m}$. In the impacted area, the deep, intermediate, and shallow sites were of $0.45,0.35$, and $0.1 \mathrm{~m}$ deep, respectively (Fig. $1 b$ ), and the distance between deep and shallow sites was $80 \mathrm{~m}$. All sites were exposed to the same amount of solar radiation.

The samplings were performed in three replicates with squares of $0.25 \mathrm{~m}^{2}$, in December 1995, when the water level was low and O. glumaepatula individuals were beginning to be covered by water. After sampling, they were measured, counted, washed for the extraction of periphyton, and dried at $60^{\circ} \mathrm{C}$ for $72 \mathrm{hrs}$. Fasciculate $O$. glumaepatula roots (attached to the sediment) were separated from the individuals and weighed. In the laboratory, the total material (fasciculate roots, leaves, culms and adventitious roots) in each square was dried again, weighed, ground, and analyzed for concentrations of organic carbon, Kjeldahl nitrogen, and total phosphorus.

Nitrogen-Kjeldahl was performed as proposed by Embrapa (1975). Approximately $0.3 \mathrm{~g}$ of sample was digested with sulfuric acid and Secatalyst mixture. The cooled sample was then transferred to a distillation flask and, after addition of $\mathrm{NaOH}$, the ammonium content was analyzed by steam distillation. Two distillates were collected in Erlenmeyer flasks with boric acid and an indicator. Ammonium was determined after distillation with diluted sulfuric acid. Total-Phosphorus was performed as a method proposed by Fassbender (1973). Approximately $0.3 \mathrm{~g}$ of sample was digested with a mixture of sulfuric, nitric, and perchloric acids. After digestion, the sample was transferred and diluted in a trial balloon flask. A solution of $\left(\mathrm{NH}_{4}\right)_{6} \mathrm{Mo}_{7} \mathrm{O}_{24} \cdot 4 \mathrm{H}_{2} \mathrm{O}$ and $\mathrm{K}_{2}\left(\mathrm{C}_{4} \mathrm{H}_{2} \mathrm{O}_{6} \mathrm{Sb}\right)_{2} \cdot 3 \mathrm{H}_{2} \mathrm{O}$ was then added. The phosphate reacts with the molybdenum, and the blue color can be determined in a spectrophotometer at $820 \mathrm{~nm}$. Concentration of organic carbon in O. glumaepatula was estimated by multiplying organic matter concentration by 0.46 , as suggested by Westlake (1968). Concentration of organic matter was obtained by gravimetry after ignition in a muffle furnace at $550^{\circ} \mathrm{C}$ for 4 hours. The $\mathrm{C}: \mathrm{N}: \mathrm{P}$ ratios were obtained from the concentrations in mols.

The Student T test was applied, with reliability of $95 \%$ for evaluation of differences among the deep, intermediate, and shallow sites in biomass, culm diameter, density, and length, and concentrations of $\mathrm{C}, \mathrm{N}$, and $\mathrm{P}$. There were 3 replicates for the chemical analyses and determination of biomass and density. Number of replicates for length and culm diameter was: Natural Area - deep $=22$, intermediate $=20$, shallow $=15$; Impacted Area deep $=5$, intermediate $=13$, shallow $=16$.

\section{RESULTS}

Concentrations of $\mathrm{C}$ in O. glumaepatula showed a significant increase ( $p>0.05$; t-test) from the deep to the shallow site in the natural area of Lake Batata (Fig. 2a). For P and $\mathrm{N}$ concentrations, this pattern was reversed: they increased significantly ( $p>0.05$; t-test) from the shallow to the deep site (Fig. 2b and c). As a consequence of these results, C:N, C:P and N:P ratios in O. glumaepatula increased from the deep to the shallow site (Table 1). In the natural area, the intermediate site presented higher biomass and density values than the deep and shallow sites ( $p>0.05$; t-test) (Fig. 3a and c), while values for the $O$. glumaepatula length in the natural area presented no significant variation ( $\mathrm{p}<0.05$; t-test) between the deep and intermediate sites. However, at the deeper site length was significantly higher ( $\mathrm{p}>0.05$; t-test) compared to the shallow site (Fig. 3b). Culm diameter of $O$. glumaepatula did not significantly vary among the three studied sites ( $\mathrm{p}<0.05$; t-test) (Fig. 3d). The ratio between biomass of fasciculate roots and total biomass (FR/TB) of $O$. glumaepatula decreased with depth increase (Table 1).

In the impacted area, concentrations of $\mathrm{C}$, $\mathrm{N}$, and $\mathrm{P}$ in the $O$. glumaepatula biomass showed a different set of patterns when compared to those found in the natural area. Concentrations of $\mathrm{C}$ were significantly higher $(\mathrm{p}>0.05$; t-test) at the deep and intermediate sites, compared to the shallow site (Fig. 2a), while the $\mathrm{P}$ and $\mathrm{N}$ concentrations of O. glumaepatula presented no significant variations ( $\mathrm{p}<0.05$; t-test) among the three sampled sites (Fig. $2 \mathrm{~b}$ and c). The $\mathrm{C}: \mathrm{N}$ ratio of $O$. glumaepatula also presented no relevant variation among these sites; however, the C:P and $\mathrm{N}: \mathrm{P}$ showed a detectable increase from the shallow to the deep site. In the impacted area, density and biomass values for $O$. glumaepatula were up to 10 times lower than in the natural area ( $\mathrm{p}>0.05$; t-test) (Fig. $3 \mathrm{a}$ and $\mathrm{c}$ ). 

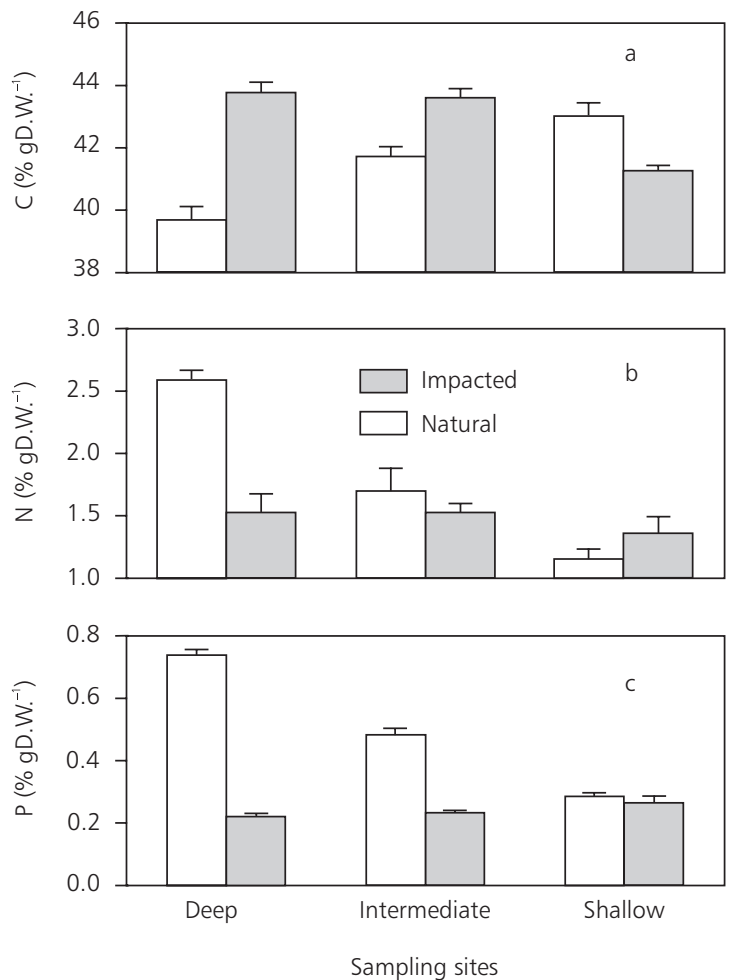

Fig. 2 - Carbon (a), nitrogen (b), and phosphorus (c) concentrations of Oryza glumaepatula at the sampling sites in the natural and impacted regions of Lake Batata (mean $\pm \mathrm{SD} ; \mathrm{n}=3$ for all elements).
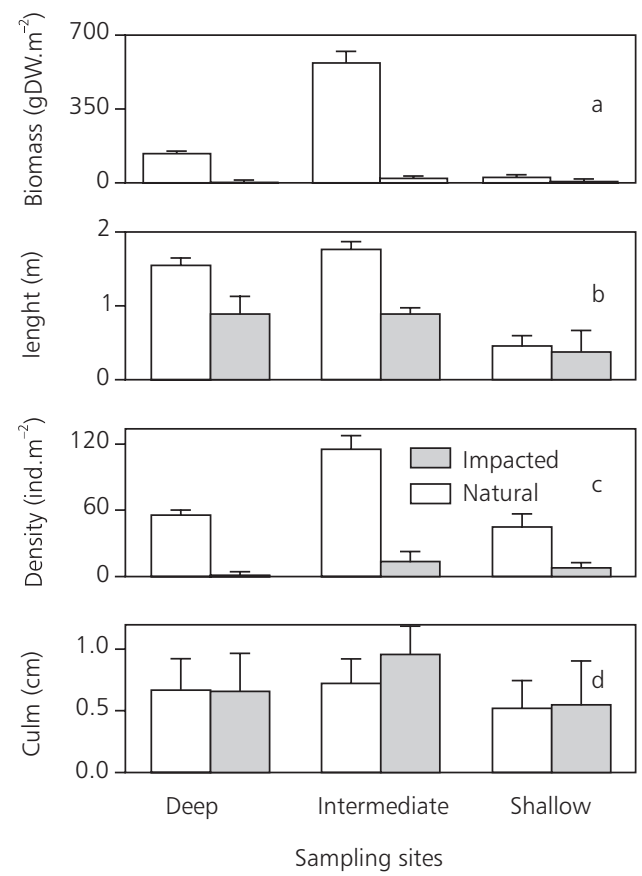

Fig. 3 - Biomass (a), length (b), density (c), and diameter of culms (d) of Oryza glumaepatula at the sampling sites in natural and impacted regions of Lake Batata (mean $\pm \mathrm{SD} ; \mathrm{n}$ for biomass and density $=3$; $\mathrm{n}$ for length and arlms, see text). 
TABLE 1

Fasciculate roots/total biomass (FR/TB) and C:N and C:N:P rations (molar basis) at the three sampling sites in natural and impacted regions of Lake Batata.

\begin{tabular}{|c|c|c|c|c|c|c|}
\hline \multirow{2}{*}{} & \multicolumn{2}{|c|}{ RF/BT } & \multicolumn{2}{c|}{ C:N } & \multicolumn{2}{c|}{ C:N:P } \\
\cline { 2 - 7 } & Natural & Impacted & Natural & Impacted & Natural & Impacted \\
\hline Deep & 6.5 & 25.6 & 18 & 33 & $137: 8: 1$ & $503: 15: 1$ \\
\hline Intermediate & 7.5 & 22.2 & 29 & 33 & $220: 8: 1$ & $476: 14: 1$ \\
\hline Shallow & 16.4 & 21.1 & 43 & 35 & $384: 9: 1$ & $395: 11: 1$ \\
\hline
\end{tabular}

Despite the difference in density between the intermediate and shallow sites not being significant in the impacted area, density and biomass were greater in the intermediate site. The length values presented the same pattern found in the natural area, with highest values at the deeper sites (deep and intermediate), but, when these two areas were compared, values were significantly higher $(\mathrm{p}>0.05$; t-test) for the natural area (Fig. 3b). O. glumaepatula culm diameter showed no significant variations among the three sites studied and between natural and impacted areas ( $p<0.05$; t-test) (Fig. 3d). The ratio between fasciculate roots and total biomass of $O$. glumaepatula showed a reverse pattern when compared to that of the natural area, increasing as depth increased, and higher in the impacted area at all three sampled sites (Table 1).

The $\mathrm{P}$ and $\mathrm{N}$ concentrations were significantly higher in the natural area $(p>0.05$; $t$-test in the deep area for both nutrients and in the intermediate area for $\mathrm{P}$ ) or did not exhibit significant differences between the two areas ( $p<0.05$; t-test) (Fig. $2 b$ and c). On the other hand, $\mathrm{C}$ concentrations in $O$. glumaepatula individuals in the impacted area were significantly higher at the deep and intermediate sites ( $p>0.05$; t-test) (Fig. 2a). The C:P and N:P ratios were higher in the impacted area at all sampling sites (Table 1).

\section{DISCUSSION}

Nutrient content variation in aquatic macrophytes may usually be explained by competition for light and nutrient (Chambers \& Kalff, 1987) or its availability (Alcoverro et al., 1997). In this study, differences in light incidence among the three sampling sites may be disregarded, since they occurred only in the first morning hours.
Field observations showed that, in the natural area, the deep and intermediate sites had dark and more organic sediment than did the shallow sites, which had sandy sediment with obviously lower concentrations of organic matter. In addition, due to the reduced water column in the shallow site, the $O$. glumaepatula individuals had no developed adventitious roots, absorbing nutrients only from the sediment. However, adventitious roots could be observed in the individuals in the intermediate and deep sites. Therefore, the results suggest that $\mathrm{P}$ and $\mathrm{N}$ availability in the sediment is less at the shallow site than at the deeper sites (intermediate and deep). According to Duarte (1992), aquatic macrophytes with high $\mathrm{C}: \mathrm{P}$ and $\mathrm{C}: \mathrm{N}$ are usually limited by $\mathrm{P}$ and $\mathrm{N}$.

Concentrations of $\mathrm{C}$ in O. glumaepatula decreased as $\mathrm{P}$ and $\mathrm{N}$ concentrations increased with depth. This may be explained by the structural function of C. In shallower sites, due to the reduced water column individuals invest in supporting structures with high C concentrations (Duarte, 1992). As the water level rises, water column pressure acts as a support for the individuals and the role of supporting structures diminishes.

If the differences in $\mathrm{P}$ and $\mathrm{N}$ concentrations in the O. glumaepatula individuals may be explained by dissimilarities in physical and chemical characteristics of the water and the sediment, they do not explain the variation between the deeper sites (deep and intermediate). Sediment of the deep and intermediate sites proved to be very organic and had visually similar characteristics, and $O$. glumaepatula individuals at both sites had developed adventitious roots. Therefore, the greater $\mathrm{P}$ and $\mathrm{N}$ concentrations in $O$. glumaepatula individuals at the deep site may be attributed to its lesser density. Competition for nutrients from the 
sediment and water column is assuredly more intense in the intermediate site when compared to the deep site, as shown by a decreased nutrient availability for individuals growing there.

Differences observed at the sampling sites could also be attributed to variation in age among the individuals since they germinate at different times. Younger $O$. glumaepatula individuals contain more $\mathrm{N}$ and $\mathrm{P}$ than older ones (unpublished data). However, this pattern is only expected before the increase in water level and inundation of the individuals. Afterwards, individuals growth has to accompany water level increase. In this case, plants have to absorb nutrients from the water column or sediment to build and increase biomass. If not, $\mathrm{N}$ and $\mathrm{P}$ concentrations will decrease in the plant, as shown by Enrich-Prast (1998). Therefore, although the deeper site individuals are younger than those from the shallow sites, their higher $\mathrm{N}$ and $\mathrm{P}$ concentration cannot be attributed to age differences.

The density and biomass of $O$. glumaepatula individuals suggest that the intermediate site presents the best conditions for germination and establishment of individuals of this species. Lower availability of organic matter in the sediment may be regarded as the main cause for lesser biomass and density of $O$. glumaepatula at the shallow site. Also, it must be said that this area is exposed for a longer period of time in the drawdown period than are the intermediate and deep sites, which may reduce the viability of exposed seeds. According to Vaughan (1989), the genus Oryza colonizes environments exposed for just a few weeks. The opposite phenomenon may have happened at the deep site, which was closer to the limnetic region and exposed for a shorter time than the intermediate site. As the length of time before germination is not constant for all seeds (Schulthorpe, 1985), the period of exposure of the deep site was possibly insufficient for germination of all seeds.

In the natural area, results of chemical composition and biometric parameter analyses of $O$. glumaepatula showed that this population has great spatial variation. In the impacted area, the absence of significant variation in the $\mathrm{N}$ and $\mathrm{P}$ concentrations in O. glumaepatula among the three sampled sites shows that the population is more spatially homogenous. This result may be attributed to the smaller spatial variation of $\mathrm{N}$ and $\mathrm{P}$ concentrations in the impacted area sediment. Esteves \& Enrich-
Prast (1997) showed that the horizontal variation of the nutrient concentration from the igapó area to the center of the lake is smaller in the impacted than in the natural area.

Esteves \& Enrich-Prast (1997) and Callisto $\&$ Esteves (1996) have also shown that nutrient concentration is lower in the impacted area sediment. This explains the lower $\mathrm{N}$ and $\mathrm{P}$ concentrations found in the individuals of $O$. glumaepatula in that area. According to Duarte $(1990,1992)$ nutrient concentrations in aquatic macrophytes usually depend on their availability in the environment (i.e., sediment). The high $\mathrm{C}: \mathrm{P}$ and $\mathrm{N}: \mathrm{P}$ ratios indicate that, in the impacted area, $\mathrm{P}$ is more limiting to the development of $O$. glumaepatula than in the natural area.

The reduced biomass and density values of O. glumaepatula in the impacted area show that bauxite tailings hinder the development of this population. As this species germinates in the crevices formed by bauxite tailing blocks, the physical space available for germination is less for individuals of the impacted area when compared to that of the natural area. In addition, decreased nutrient availability in the impacted area sediment must be considered (Callisto \& Esteves, 1996; Esteves \& Enrich-Prast, 1997).

The higher fasciculate root/total biomass ratios in the impacted area may also be attributed to lower nutrient concentrations in the sediment. To overcome this, individuals of $O$. glumaepatula allocate more biomass to a structure acting in the uptake of these nutrients, a pattern also observed by Enrich-Prast (1998). This author has also shown that magnitude of the culm diameter is a parameter indicating morphological changes in O. glumaepatula populations due to water level variation and the bauxite tailings. In this research, however, no variation in culm diameter was observed, a fact attributed to the little time available for the $O$. glumaepatula individuals to show morphological changes. The lesser $O$. glumaepatula lengths in the impacted area may be explained by the simple fact that the water in this area is shallower.

The biomass results obtained by Enrich-Prast (1998) diverge from those found here, since this author concluded that the $O$. glumaepatula biomass is greater in the impacted area as compared to the natural area. These conclusions were reached after two years of quarterly sampling at Lake Batata and were attributed to the decreased intraspecific com- 
petition in the $O$. glumaepatula population in the impacted area. This difference between the results of these studies may be due to the great water level variation in the course of one year, which completely modifies the physical and chemical conditions of the water column, causing great temporal variation in $O$. glumaepatula biometric parameters. However, in the low water period (when this study was carried out), the results found by Enrich-Prast (1998) were the same as those found in this research, with lower values for O. glumaepatula biomass in the impacted area.

Acknowledgments - We would like to thank the Company Mineração Rio do Norte for financial support, to CNPq and CAPES for scholarships, to MSc. Paulo Brum for translating the manuscript into English, and to Ricardo Maia for drawing Fig. 1.

\section{REFERENCES}

ALCOVERRO, T., ROMERO, J., DUARTE, C. M. \& LOPEZ, N. I., 1997, Spatial and temporal variations in nutrient limitation of seagrass Posidonia oceanica growth in the NW Mediterranean. Mar. Ecol. Prog. Ser., 146: 155-161.

CHAMBERS, P. A. \& KALFF, J., 1987, Light and nutrients in the control of aquatic plant community structure. I. In situ experiments. J. Ecol., 75: 611-619.

CALLISTO, M. \& ESTEVES, F. A., 1996, Macroinvertebrados bentônicos em dois lagos amazônicos: lago Batata (um ecossistema impactado por rejeito de bauxita) e lago Mussurá. Acta Limnol. Bras., 8: 137-147.

DUARTE, C. M., 1990, Seagrass nutrient content. Marin. Ecol. Prog. Ser., 67: 201-207.

DUARTE, C. M., 1992, Nutrient concentration of aquatic plants: patterns across species. Limnol. Oceanogr., 37: 882-889

EMBRAPA, SNLCS, 1975, Manual de análise de solos II. (Mimeografado). Rio de Janeiro.

ENRICH-PRAST, A., 1998, Biometria e concentrações de fósforo, nitrogênio, carbono e teor da macrófita aquática Oryza glumaepatula Steud em um lago amazônico impactado por rejeito de bauxita (Lago Batata-PA). Dissertação de Mestrado, UFRJ, Rio de Janeiro, 82p.
ESTEVES, F. A., BOZELLI, R. L. \& ROLAND, F., 1990, Lago Batata - Um laboratório de limnologia tropical. Ciência Hoje, 11: 26-33.

ESTEVES, F. A. \& ENRICH-PRAST, A., 1997, Taxas de fixação de nitrogênio (redução de acetileno) em sedimento de igapó natural e impactado com rejeito de bauxita em um lago amazônico (Lago Batata, PA). Anais do VIII Sem. Reg. Ecol., VIII: 199-208.

FASSBENDER, H. W., 1973, Simultane P-Bestimmung im N-Kjeldahl-aufschlubb von Bodenproben. Die Phosphorsäure, 30: 44-53.

JUNK, W. J. \& PIEDADE, M. T. F., 1993, Biomass and primary production of herbaceous plant communities in the Amazon floodplain. Hydrobiologia, 263: 155-162.

MORISHIMA, H. \& MARTINS, P. S., 1994, Investigations of plant genetic resources in the Amazon basin with the emphasis on the genus Oryza. Rep. Amazon Project, Fapesp, 100p.

PANOSSO, R., MUEHE, D. \& ESTEVES, F. A., 1995, Morphological characteristics of an Amazon floodplain lake (Lake Batata, Pará State, Brazil). Amazoniana, XIII: 245 258.

PIEDADE, M. T. F., 1995, Biologia e ecologia de Echinochloa polystachya (H.B.K.) Hitchcock (Poaceae), capim semiaquático da várzea amazônica. Acta Limnol. Bras., 6: 173185.

RUBIM, M. A. L., 1995, Ciclo de vida, biomassa e composição química de duas espécies de arroz silvestre da Amazônia Central. Dissertação de Mestrado, INPA, Manaus, $126 \mathrm{p}$.

SCHULTHORPE, C. D., 1985, The biology of aquatic vas cular plants. Germany, Koeltz Scientific Books, $2^{\text {nd }}$ ed., $610 \mathrm{p}$.

SIOLI, H., 1984, The Amazon and its main effluents: Hydrography, morphology and river types. In: H. Sioli (ed.), The Amazon: Limnology and landscape ecology of a might tropical river and its basin. Dr. W. Junk Publ., Dordrecht, pp. 127-165.

VAUGHAN, D. A., 1989, The genus Oryza L. Current status of taxonomy. IRRI Research Paper Series, Number 138.

WESTLAKE, D. F., 1968, Primary production rates from changes in biomass macrophytes. In: R. A. Vollenweider (ed.), A manual of methods for measuring primary production in aquatic environments. Oxford, Blackwell, pp. 103-107. 